\title{
GDF9 Gene
}

National Cancer Institute

\section{Source}

National Cancer Institute. GDF9 Gene. NCI Thesaurus. Code C24426.

This gene plays a role in ovarian folliculog enesis and normal ovulation. 